Artículo científico

Volumen 30(3):681-693. Septiembre-diciembre, 2019

e-ISSN 2215-3608, doi:10.15517/am.v30i3.36307

http://www.revistas.ucr.ac.cr/index.php/agromeso

\title{
Evaluation of irrigation and pruning on the phenology and yield of Theobroma cacao L. ${ }^{1}$
}

\section{Evaluación de riego y poda sobre la fenología y rendimiento en Theobroma cacao L.}

\author{
Diego Hernán Meneses-Buitrago², Martha Marina Bolaños-Benavides ${ }^{3}$, Luis Fernando Gómez-Gil", \\ Housseman Steven Ramos-Zambrano ${ }^{2}$
}

1 Receipt: February $27^{\text {th }}, 2019$. Acceptation: June $17^{\text {th }}, 2019$. This work was part of the project "Risk reduction and adaptation to climate change, adaptation models and agroclimatic prevention (MAPA)", executed by the Corporación Colombiana de Investigación Agropecuaria (AGROSAVIA) with resources from Fondo de Adaptación Colombia.

2 Corporación Colombiana de Investigación Agropecuaria (AGROSAVIA), Centro de Investigación Obonuco, Pasto, Colombia. dmeneses@ agrosavia.co (https://orcid.org/0000-0003-3033-3079), hramos@agrosavia.co

3 Corporación Colombiana de Investigación Agropecuaria (AGROSAVIA), Centro de Investigación Tibaitata, Bogota, Colombia.mmbolanos@ agrosavia.co

4 Corporación Colombiana de Investigación Agropecuaria (AGROSAVIA), Centro de Investigación Obonuco, Pasto, Colombia. lfgomezg@ gmail.com (Until November 22 $\left.2^{\text {th }}, 2016\right)$.

\begin{abstract}
Introduction. It is believed that only $0.5 \%$ of the area planted worldwide with cocoa is irrigated. Water availability influences the rate of expansion of the tree canopy and thus light interception. Another extremely important factor is pruning, which influences the production of floral sprouts that will give rise to new fruits, influencing productivity. Objective. The objective of this study was to evaluate the effect of drip irrigation and pruning on the performance, phenology and phytosanitary behavior of cacao trees. Materials and methods. The study was developed between 2015 and 2016 in the Cauca department, Colombia. The six-year-old trees were subjected to two watering layers: L-100\% and L-0 \% and two pruning levels: soft and strong. Total number of fruits, number of healthy and sick fruits, kg of wet and dry cocoa, fruit index and seed index, longitudinal and equatorial diameters and incidence of Moniliopthora roreri, Phytophthora palmivora and Monalonion dissimulatum were evaluated. The growth and development curves of the fruit throughout time were built. An experimental design of complete random blocks was used in an arrangement of divide plots. Results. Fruit index varied from 22 (T2) up to 33 fruits (T3), the seed index varied from $0.91 \mathrm{~g}$ (T4) to 1.14 $\mathrm{g}$ (T2). There were no other significant results for other variables. Conclusion. From a technical and economic point of view an optimal response to the interaction of irrigation with the two levels of pruning was observed because, with a timely application of watering and an adequate pruning management, crop performance can be increased, harvests can be programmed and better quality fruits can be obtained.
\end{abstract}

Keywords: water balance, trickle irrigation, productivity.

\section{Resumen}

Introducción. Se cree que solo el $0,5 \%$ de la superficie plantada a nivel mundial con cacao es irrigada. La disponibilidad de agua influye en la tasa de expansión de la copa y, por lo tanto, en la interceptación de la luz. Otro 
factor de gran importancia es la poda, que influye en la producción de cojines florales que darán origen a frutos, e influirán en la productividad. Objetivo. El objetivo de este estudio fue evaluar el efecto del riego por goteo y la poda en el rendimiento, la fenología y comportamiento fitosanitario del cacao. Materiales y métodos. El estudio se desarrolló entre el año 2015 y el 2016, en el departamento del Cauca, Colombia. Los árboles de seis años de edad fueron sometidos a dos láminas de riego: L-100 \% y L-0 \%, y dos niveles de poda: suave y fuerte. Se evaluó el total de mazorcas, mazorcas sanas, mazorcas enfermas, $\mathrm{kg}$ de cacao húmedo, $\mathrm{kg}$ de cacao seco, índice de mazorca y de semilla, diámetro longitudinal y ecuatorial de los frutos, incidencia de Moniliopthora roreri, Phythophthora palmivora y Monalonion dissimulatum. Se construyeron las curvas de crecimiento y desarrollo del fruto en el tiempo. Se utilizó un diseño experimental de bloques completos al azar en un arreglo de parcelas divididas. Resultados. El índice de mazorca varió de 22 (T2) a 33 mazorcas (T3), el índice de semilla varió de 0,91 g (T4) a 1,14 g (T2), para otras variables no se reportaron diferencias significativas. Conclusión. Desde el punto de vista técnico y económico se evidenció respuesta óptima por efecto de la interacción del riego con los dos niveles de poda, ya que con una aplicación oportuna del riego y el manejo adecuado de las podas, puede aumentarse el rendimiento, programar cosechas y obtener mejor calidad de los frutos.

Palabras clave: balance hídrico, riego por goteo, productividad.

\section{Introduction}

The world production of cocoa beans fell by $3 \%$ during 2014/2015 reaching 4,236 million t. Although, the production of Côte d'Ivoire in Africa rose to a record high number of 1,796 million t surpassing the previous season, in Ghana the accumulated purchases of cocoa beans by the Ghana Cocoa Board during 2014/2015 was stated in $740,000 \mathrm{t}$, a decrease of $157,000 \mathrm{t}$ compared to the previous official campaigns. Though the combined production of the America increased by $36,000 \mathrm{t}$ to $763,000 \mathrm{t}$, Oceania and Asian harvests decreased by almost $11 \%$ to $400,000 \mathrm{t}$; this fall largely corresponded to Indonesia (ICCO, 2017).

In terms of its share of total world production, Africa remained the largest cocoa producing region, with 73 $\%$ of the world production, meanwhile the quotas of the Americas, Asia and Oceania remained in $18 \%$ and $10 \%$, respectively (ICCO, 2017).

In Colombia, according to the agricultural statistics of DANE (2016), cocoa is cultivated in 22 departments in an area of 110,795 ha, with an annual production of 71,143 t. However, $85 \%$ of the area and production is concentrated in the departments of Santander, Antioquia, Cesar, Tolima, Huila, North of Santander, Boyacá, and Cauca. Cauca occupies the eighth place in the cultivated area $(2,974 \mathrm{ha})$, the ninth place in production $(1,474 \mathrm{t}$ year $\left.{ }^{-1}\right)$ and the eleventh place in yield $\left(0.6 \mathrm{t} \mathrm{ha}^{-1}\right.$ year $\left.^{-1}\right)$.

According to the Autonomus Regional Corporation of Cauca (CRC, 2010), the municipalities of Mercaderes and Florencia, have the lowest water regulation indices in the department, it is, low regulation capacity and high vulnerability due to resource scarcity. Despite being a municipality vulnerable to drought, cocoa cultivation has positioned itself as a promising alternative, due to the soil properties and the social and economic conditions of the region. Cocoa is a productive line with less vulnerability to the effects of climate change, because there are different management strategies as the use of shade canopies, the employment of irrigation and clones resistant to drought and high temperatures (Andrade et al., 2013).

It is believed that only a very small proportion $(0.5 \%)$ of the area planted worldwide with cocoa is irrigated. According to Carr and Lockwood (2012), water availability can influence the rate of expansion of the canopy, and therefore, light interception, which in turn affects crop productivity. 
Despite the apparent sensitivity of cocoa to drought, few irrigation experiment results have been reported up to date, probably due to the high costs of implementing this type of technology (Carr and Lockwood, 2012). In one study, cocoa plants cultivated in pots were irrigated after a period of water stress, the phenological stage of new leaf budding was stimulated approximately ten days after irrigation, followed by the leaf maturation phase, that then leads to the reproductive stage through flowering (Salef, 1970).

An experiment where plants were transferred from low relative humidity (50-60\%) or medium (70-80\%) to high relative humidity (90-95\%), demonstrating that the relief of water stress could also induce flowering by satisfying the water needs of the cocoa plant (Sale, 1969).

In a study carried out in the Chongon Experimental Farm in the Guayas province (Ecuador), the effect of drip irrigation and micro-sprinkling on the productivity of the cocoa clone CCN 51 was evaluated. Results showed that with drip irrigation, using $80 \%$ of the programmed irrigation sheets, higher yields were obtained, and there was no detriment in annual production per hectare (Romero and Proaño, 2008).

Another factor of great importance, and on which production success depends, is the adequate execution of shape and maintenance prunings because these build the architecture of the tree and which guarantee the production of floral cushions that will give rise to future fruits. Furthermore, Chinin (2015) evaluated three forms of pruning: 1. branches without pruning and branch thinning, 2. branches with pruning and branch thinning, and 3. pruning without thinning, besides evaluating a control (without pruning). The pruning that obtained a higher yield was branches with pruning and thinning, obtaining a value of 1,400 $\mathrm{kg} \mathrm{ha}^{-1}$. Employing the Penman-Monteith method, the evapotranspiration was calculated, which was $3.44 \mathrm{~mm} \mathrm{day}^{-1}$ of the ETo. The water needs of the crop during its vegetative period were 3.361 per plant.

The productivity of cocoa in response to crown pruning in the San Francisco farm, municipality of Cárdenas (Tabasco, Mexico) was evaluated for López et al. (2016), and they concluded that this type of pruning is an alternative to increase crop productivity, with little investment and good advice to execute it.

According to what was mentioned above, the objective of this study was to evaluate the effect of drip irrigation and pruning on the performance, phenology, and phytosanitary behavior of cocoa trees.

\section{Materials and methods}

The work was developed in the San Joaquín corregimiento, village of La Monja, Mercaderes, department of Cauca, Colombia, located at 1,170 m.a.s.l. with clay loam soils. The average annual rainfall of the study site is $1,500 \mathrm{~mm}$, with the evaporation of $1,600 \mathrm{~mm} \mathrm{year}^{-1}$, an average relative humidity of $80 \%$ and an average annual temperature of $26^{\circ} \mathrm{C}$.

Two irrigation sheets were defined from the reference evapotranspiration (ETo) values of the study location as follows: L1: $100 \%$ and L2: $0 \%$. Irrigation was applied daily, giving the crops the exact amount of consumption generated by ETo. In order to establish the irrigation sheet to be applied, humidity gains and losses were taken into account, generating a water balance using the FAO-Penman-Monteith method (Allen et al., 2006). To calculate evapotranspiration, the ETo calculator software, developed by FAO was used, which employs the FAO PenmanMonteith equation, i.e., uses the temperature and precipitation data measured by an automatic meteorological station to calculate the reference crop evapotranspiration (ETo).

To calculate crop evapotranspiration (consumptive use), the related Kc coefficient corresponds to different development stages; meanwhile, for the design of the irrigation system, the coefficient of the final growth stage was used. The water sheets were applied through a drip irrigation system with four emitters per tree (self-compensating drippers) with a performance of $4 \mathrm{l} \mathrm{h}^{-1}$, and as a water source, the surface water of a torrential stream was used.

Two pruning treatments were established: soft pruning and strong pruning, which are described next: 
Strong pruning: basically, consisted on cutting dry, sick, teared up, crossed and bad driven branches, parasite plants, epiphytic plants, climbing plants, cropping or tree height regularization, branches regularization, lateral cropping when crossing with near trees is detected, branches regularization with an excessive development of dominance with higher intensity cropping (Palencia y Mejía, 2000).

Soft pruning: it consisted of cropping of lateral branches and tree height regularization.

These two types of pruning were assigned at random to every experimental unit, resulting in the next treatments applied to the experimental cocoa crops:

During 2015 (October, November and December) and 2016 (January, February, March, April and May) were evaluated the crop performance $\left(\mathrm{t} \mathrm{ha}^{-1}\right)$, fruit growth, wet and dry cocoa weight, seed index, which was the average weight in grams of 100 fermented and dry seeds taken at random (Eskes et al., 2000), and fruit index, which was the number of fruits needed to get one $\mathrm{kg}$ of fermented and dry cocoa (Eskes et al., 2000).

The seed index was determined using an electronic weighing scale with a precision of $0.001 \mathrm{~g}$; diameter and growth of the fruit were measured with a digital gauge. Moreover, the incidence of the main phytosanitary disturbances, total healthy and sick fruits were evaluated as well.

Likewise, the dynamics of the diseases and pests such as moniliasis (Moniliophthora roreri), black pod (Phytophthora palmivora) and monalonium (Monalonion dissimulatum) that appeared during the development of the experiment were registered as the percentage of incidence, considering the following formula:

$$
\% \text { of incidence }=\frac{\text { No. of fruits affected }}{\text { No. fruits harvested }} * \mathbf{1 0 0}
$$

The meteorological variables to calculate water balance and the estimation of the ETo were obtained from an automatic meteorological station with precipitation, temperature, relative humidity, solar brightness, wind speed, and dew point sensors.

A randomized complete block design was used with an arrangement of divided plots, four treatments, three replications, and four trees per repetition, for a total of twelve trees per treatment. In the main plot, the effect of drip irrigation was evaluated, and in the sub-plots, crop management with the application of the two pruning levels was assessed. The treatments applied arise from the interaction among the levels of each factor (Table 1).

Table 1. Treatments applied to the experimental cultivation of cacao in the village of La Monja, municipality of Mercaderes, Cauca, Colombia. 2015-2016.

Cuadro 1. Tratamientos aplicados al cultivo experimental de cacao en el pueblo de La Monja, municipio de Mercaderes, Cauca, Colombia. 2015-2016.

\begin{tabular}{c}
\hline Treatments \\
\hline T1 : Drip irrigation + strong pruning \\
T2 $:$ Drip irrigation + soft pruning \\
T3 $:$ Without irrigation + strong pruning \\
T4 : Without irrigation + soft pruning \\
\hline
\end{tabular}

The economic analysis was carried out based on the weighted average data methodology framed in weighted estimations based on the variations in temporal performance (Llinás, 2014). Thus, the data was estimated based on harvest periods and the productive cycle for cloned cacao (10 years average) concerning its average deviation in order to establish, through partial data, monthly and annual fluctuations in the period above. On these data, the 
cash flow was estimated considering the historical producer price in the area (income) and costs (expenses) by alternative, thus, establishing the utility obtained with the implementation of each proposed technological option. The monetary calculations used in the comparison of productivity, price and profitability variables were defined from the historical average of the United States dollar in Colombia for the year 2018 (1 USD = COP: \$2,956.43); in addition, the following indicators were used to validate the information:

Equation 1. Net present value (NPV), used to identify the profitability of the treatments (Puentes, 2011).

$$
n_{P} v=\sum_{i=1}^{n} \frac{v_{t}}{(1+k)^{t}}-I_{0}
$$

(equation 1)

Where:

$V_{t}$ : Cash flows in each period $t$.

$I_{0}$ : Value of the initial disbursement of the investment.

$t$ : Number of periods considered.

$k$ : Discount or return rate that can be earned in another alternative.

Equation 2. Internal rate of return (IRR), used to identify the profitability of the treatments (Mete, 2014).

$$
I R R=\sum_{T=0}^{n}=\frac{F n}{(1+i)^{n}}=0
$$

Where:

$F_{n}$ : Cash flow in period $n$.

$n$ : Number of periods.

$i$ : Value of the initial investment.

Equation 3. Investment recovery period (IRP), used to identify the profitability of treatments (Cubbage et al., 2011).

$$
I R P=a+\left(\frac{b-c}{d}\right) \quad \text { (equation 3) }
$$

Where:

$a$ : The immediately previous year in which the investment is recovered.

$b$ : Initial investment.

$c$ : Cumulative cash flow from the previous year in which the investment is recovered.

$d$ : Cash flow of the year in which the investment is recovered.

Equation 4. Cost-benefit ratio (B/C), used to identify the profitability of the treatments (Gittinger, 1983).

$$
B / C=N P V / C I V \quad(\text { equation } 4)
$$


Where:

NPV: Net present value.

CIV: Current investment value.

\section{Results}

The behavior of precipitation and evaporation during the development of this research is shown in Figure 1, which corresponds to the atmospheric water balance for the experimental plot in the period between October 1, 2015 to May 31, 2016, where low precipitation (Ppt) values were reported compared with high evapotranspiration (Eto) values, causing a negative atmospheric water balance.

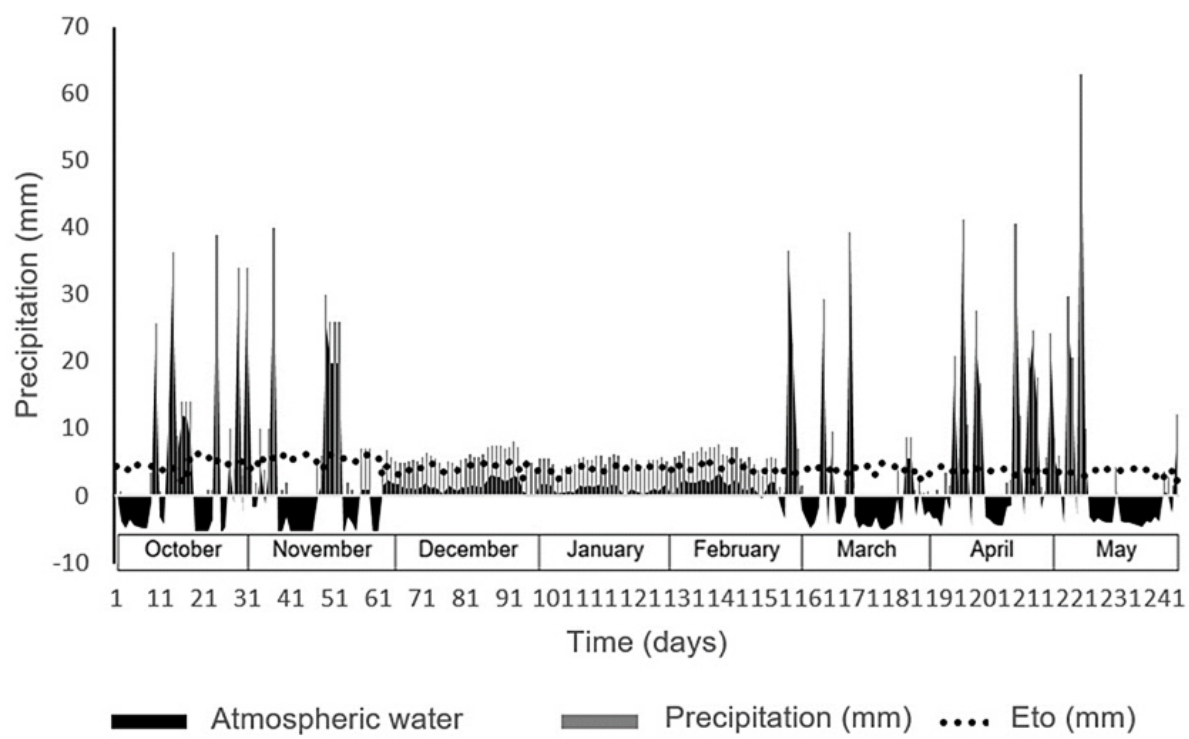

Figure 1. Daily atmospheric water balance during the experimental cultivation of cocoa (Theobroma cacao L.) in the village of La Monja, municipality of Mercaderes, Cauca, Colombia. 2015-2016.

Figure 1. Balance hídrico atmosférico diario durante el cultivo experimental de cacao (Theobroma cacao L.) en el pueblo de La Monja, municipio de Mercaderes, Cauca, Colombia. 2015-2016.

The dynamics of water in soil during the evaluation period in the cocoa production system are described into Figure 2, where the periods in which the atmospheric water deficit occurred to coincide with the record of agricultural water deficit, in which the depletion sheet in the root zone (Dr) (water that was extracted from the soil) was greater than the easily usable water (EUW) (water available to the plants) during the two periods. The first period was during the month of October until the beginning of November, and the second period was during the months of April and May. This behavior indicates that during these two periods there were water deficit conditions for the cocoa crop, which was reflected in the water stress coefficient (Ks), in which a value of 1 indicated optimal humidity conditions and values closer to 0 , indicated a higher stress degree.

The evaluation of the fruit index and seed index according to the analysis of variance, showed statistically significant differences $(\mathrm{p}=0.0001)$ between treatments (Table 2$)$. 


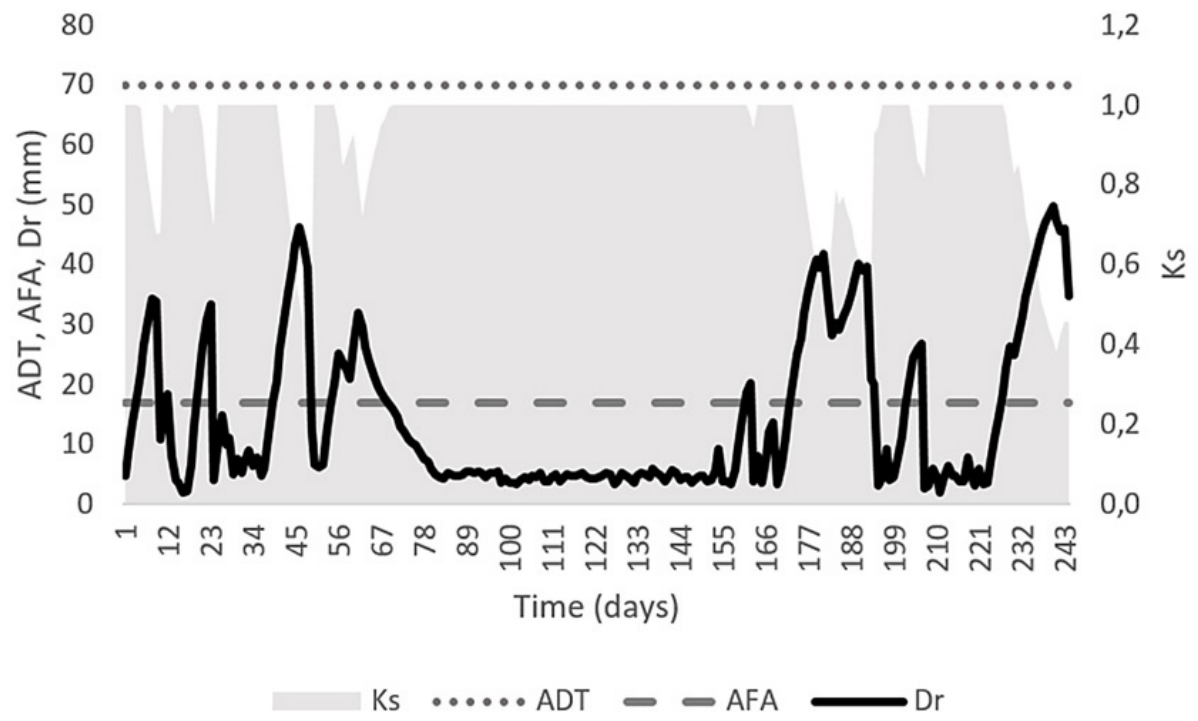

Dr: depletion sheet in the root zone, AFA: easily usable water, ADT: total available water, Ks: water stress coefficient / Dr: lámina de agotamiento en la zona de raíces, AFA: agua fácilmente aprovechable, ADT: agua disponible total, Ks: coeficiente de estrés hídrico.

Figure 2. Agricultural water balance during the experimental cultivation of cocoa (Theobroma cacao L.) in the municipality of Mercaderes, Cauca, Colombia. 2015-2016.

Figura 2. Balance hídrico agrícola durante el cultivo experimental de cacao (Theobroma cacao L.) en el municipio de Mercaderes, Cauca, Colombia. 2015-2016.

Table 2. Coverage index and seed index values (dependent variables) for the experimental cultivation of cocoa (Theobroma cacao L.) in the village of La Monja, municipality of Mercaderes, Cauca, Colombia. 2015-2016.

Cuadro 2. Valores del índice de cobertura e índice de semilla (variables dependientes) para el cultivo experimental de cacao (Theobroma cacao L.) en el pueblo de La Monja, municipio de Mercaderes, Cauca, Colombia. 2015-2016.

\begin{tabular}{ccc}
\hline Treatments & Fruit index & Seed index \\
\hline T 1 & $1.120^{\mathrm{b}}$ & $1.120^{\mathrm{b}}$ \\
T 2 & $1.140^{\mathrm{a}}$ & $1.140^{\mathrm{a}}$ \\
T 3 & $1.130^{\mathrm{b}}$ & $1.130^{\mathrm{b}}$ \\
T 4 & $0.910^{\mathrm{b}}$ & $0.910^{\mathrm{b}}$ \\
\hline
\end{tabular}

\footnotetext{
* Means with a different superscript letter are significantly different $(\mathrm{p}<0.05) / *$ Medias con diferentes letras en el superíndice son
} significativamente diferentes $(\mathrm{p}<0,05)$.

For the other variables under evaluation, there were no statistically significant differences (Table 3). It can be argued that the irrigation and pruning treatments applied did not achieve a statistically significant effect on these variables.

In trees that received the four tested treatments, $\mathrm{T} 2$ produced the maximum growth values for longitudinal diameter (LD) and equational diameter of cocoa fruits; this contrasts with T3 that showed the lowest values (Figures 3 and 4). 
Table 3. Dependent variables evaluated for the experimental cultivation of cocoa (Theobroma cacao L.) in the village of La Monja, municipality of Mercaderes, Cauca, Colombia. 2015-2016.

Cuadro 3. Variables dependientes evaluadas para el cultivo experimental de cacao (Theobroma cacao L.) en el pueblo de La Monja, municipality of Mercaderes, Cauca, Colombia. 2015-2016.

\begin{tabular}{cc}
\hline Variable & Mean \\
\hline Longitudinal diameter $(\mathrm{cm})$ & 0.057 \\
Equatorial diameter (cm) & 0.157 \\
Incidence of M. roreri (\%) & 0.218 \\
Incidence of P. palmivora (\%) & 0.400 \\
Incidence of M. dissimulatum (\%) & 0.292 \\
kg of wet cocoa & 0.717 \\
kg of dry cocoa & 0.729 \\
Number of fruits & 0.784 \\
Healthy fruits & 0.863 \\
Sick fruits & 0.638 \\
\hline
\end{tabular}

\section{Longitudinal diameter}

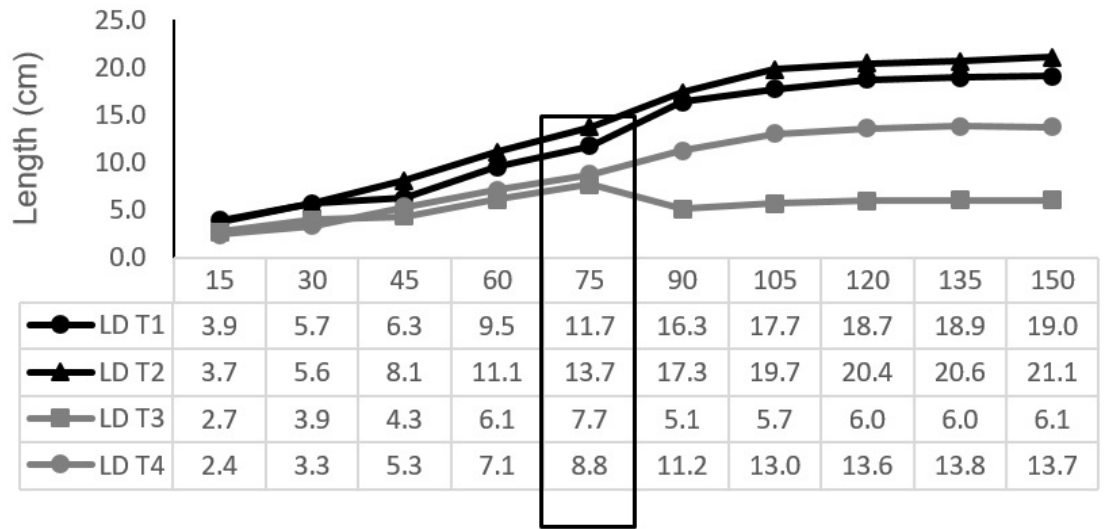

Time (days after setting or ripening)

Figure 3. Longitudinal diameter of cocoa (Theobroma cacao L.) fruit for the experimental cultivation in the village of La Monja, municipality of Mercaderes, Cauca, Colombia. 2015-2016.

Figura 3. Diámetro longitudinal del fruto del cacao (Theobroma cacao L.) para el cultivo experimental en el pueblo de La Monja, municipio de Mercaderes, Cauca. Colombia. 2015-2016.

The trees of the treatment with a water sheet of $0 \%$ of the ETo and soft pruning produced an average annual yield of $576.4 \mathrm{~kg} \mathrm{ha}^{-1}$, meanwhile with the implementation of $0 \%$ water sheet of ETo and strong pruning, a decrease of $-29 \%$, equivalent to $410.4 \mathrm{~kg} \mathrm{ha}^{-1}$ was observed. Cocoa trees that received treatment T2, i.e., $100 \%$ of the ETo and soft pruning showed an annual increase in production of approximately $83 \%\left(1,052.6 \mathrm{~kg} \mathrm{ha}^{-1}\right)$. This is why this option is the best in terms of yields; and finally, trees that received treatment with $100 \%$ water sheet of the ETo and strong pruning displayed a slight growth in productivity of $9 \%$ (Table 4$)\left(626.3 \mathrm{~kg} \mathrm{ha}^{-1}\right)$. 


\section{Equatorial diameter}

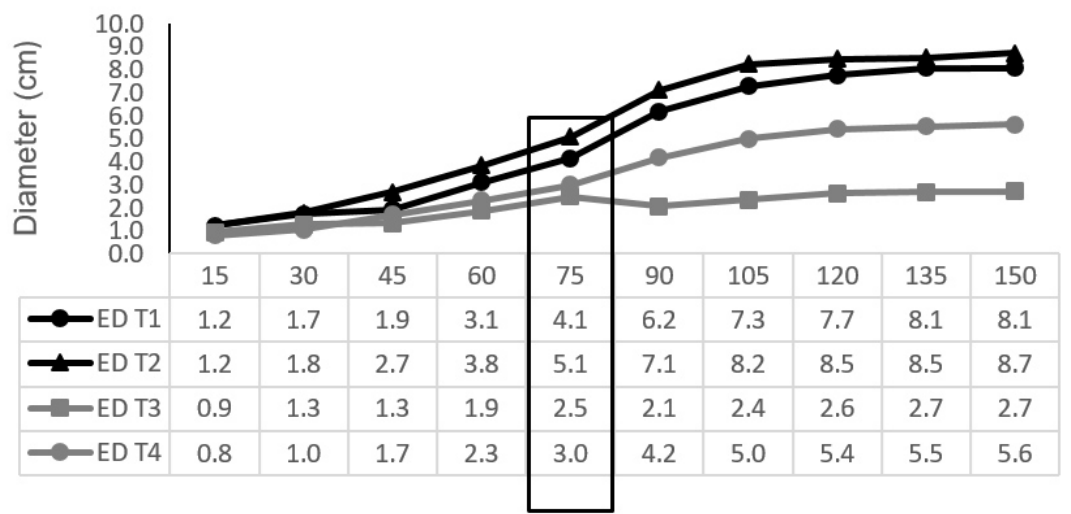

Time (days after setting or ripening)

Figure 4. Equatorial diameter of cocoa (Theobroma cacao L.) fruit for the experimental cultivation in the village of La Monja, municipality of Mercaderes, Cauca, Colombia. 2015-2016.

Figura 4. Diámetro ecuatorial del fruto del cacao (Theobroma cacao L.) para el cultivo experimental en el pueblo de La Monja, municipio de Mercaderes, Cauca. Colombia. 2015-2016.

Table 4. Comparison of the variables productivity, prices and profitability (USD) of cocoa (Theobroma cacao L.) crops (product of a 10-year projection) among treatments (T1, T2, T3, and T4) in the municipality of Mercaderes, Cauca, Colombia. 2015-2016.

Cuadro 4. Comparación de las variables productividad, precios y rentabilidad (USD) del cultivo de cacao (Theobroma cacao L.) (producto de una proyección de diez años) entre tratamientos (T1, T2, T3 y T4) en el municipio de Mercaderes, Cauca, Colombia. 2015-2016.

\begin{tabular}{|c|c|c|c|c|c|c|c|}
\hline Treatments & $\mathbf{T 4}$ & T3 & $\begin{array}{c}\text { VAR } 1 \\
(\%)\end{array}$ & $\mathbf{T} 2$ & $\begin{array}{c}\text { VAR } 2 \\
(\%)\end{array}$ & T1 & $\begin{array}{c}\text { VAR } 3 \\
(\%)\end{array}$ \\
\hline Productivity (kg ha' ${ }^{-1}$ year $\left.^{-1}\right)$ & 576.4 & 410.4 & -29 & $1,052.6$ & 83 & 626.3 & 9 \\
\hline Producer price (COP) & USD 2,3 & USD 2,3 & 0 & 2,3 & 0 & USD 2,3 & 0 \\
\hline Profitability (income year ${ }^{-1}$ ) & USD 1,350 & USD 961 & -29 & USD 2,465 & 83 & USD 1,467 & 9 \\
\hline
\end{tabular}

VAR $1(\%)$ : variation percentage of T3/T4; VAR $2(\%)$ : variation percentage of T2/T4; VAR $3(\%)$ : variation percentage of T1/T4 / VAR $1(\%)$ : porcentaje de variación de T3/T4; VAR $2(\%)$ : porcentaje de variación de T2/T4; VAR 3 (\%): porcentaje de variación de T1/T4.

Although the alternative with the highest productivity index contemplates the treatment with drip irrigation, it must be considered that its implementation implies a considerable initial investment (approximately USD 1,351 per hectare), which covers 1,111 cocoa trees at planted at a distance of $3 \times 3 \mathrm{~m}$.

The adoption of this technology, implies a higher IRR evident in the recovery of the investment in a mediumterm; for that matter, as of the sixth year, the gross income surpasses the accumulated production cost, also considering the costs incurred in the initial phase of the crop. 


\section{Discussion}

Drip irrigation and soft pruning (T2) had a positive effect on cocoa trees since they had the highest fruit production average (43 fruits), compared to trees that received other treatments. This behavior is due to the fact that the trees to which a strong pruning was applied require the formation of new secondary and tertiary branches. Likewise, when eliminating branches that are carried out in strong pruning, floral cushions that would eventually become shaped fruits can be lost.

It was observed that the trees that received soft pruning had the highest number of diseased fruits independent of the irrigation. This agrees with what Sarabia (2008) found, who mentioned that in plantations in which pruning practices have not been carried out, trees had developed compact crowns with two or more strata, completely closing the foliage and avoiding ventilation; therefore, a microclimate is generated in which there is a greater incidence of phytosanitary problems.

In terms of yield, there is higher production of wet and dry grains in those cocoa trees that received drip irrigation; further, the best treatment was the one combining drip irrigation and soft pruning (T2) compared to the other treatments (T1, T3, T4). According to Rubiano (1988), water supply through an irrigation system in cocoa generates good results in terms of precocity, growth, and increase in yields, reaching dry cocoa yield values of $1,000 \mathrm{~kg} \mathrm{ha}^{-1}$ year $^{-1}$.

It was observed that the trees that received a mild or soft pruning (T2 and T4) showed better wet and dry almond weight, compared with those that received strong pruning. This agrees with what has been described by Sarabia (2008), who comments that tree fruiting with strong pruning takes more time in relation to those trees that receive a soft pruning. The same author expresses that although the practice of strong pruning represents a level of drastic intervention to trees, this provides the opportunity to stimulate the formation of a new and more functional crown if it is supported with adequate management.

The fruit index varied from 22 (T2) to 33 fruits (T3), where the cocoa trees that received T2 obtained the lowest fruit index needed to produce one kilogram of dry cocoa grains, was the best treatment compared to the other treatments. This showed the positive effect of drip irrigation on the quality of the fruit, as stated by Rubiano (1988), who mentioned that with the inclusion of drip irrigation, better fruit quality can be obtained.

Higher average rates than recorded in this study (27 fruits) were reported by Ayestas (2009). The introduction of cloned material, selection, and natural crossing among the materials have caused that curtained materials show excellent rated of growing.

The seed index varied from $0.91 \mathrm{~g}$ (T4) to $1.14 \mathrm{~g}$ (T2) with an average of $1.15 \mathrm{~g}$. An study, reported a seed average of $1.2 \mathrm{~g}$ for cocoa clones (Ayestas, 2009), similar to the one found in this study. Applying the minimum value of the chocolate industry of $1 \mathrm{~g}$, most of the evaluated trees showed a higher rate of seeds.

A higher LD and ED was observed in the trees that received treatment followed by those that received treatment $\mathrm{T} 1$, which may be the result of the genetic variability existing within the experimental cultivation. This causes that these variables can be influenced much more by the genetics and phenotypic characteristics of the fruits of each material, and be less influenced by the interaction of irrigation and pruning factors. However, cocoa plants that received treatment T1 coincided with the results obtained by Alcaráz (1973), in which the size of the fruit was highly influenced by water availability, and therefore, fruits developed during the dry seasons were smaller than those produced under adequate humidity conditions.

The curves of fruit growth and optimum harvest time of the same lasted approximately 150 days. Temperature affects the rate of fruit development, i.e., growth rate rises with increasing temperature (Alcaráz, 1973). This coincides with what was observed in the period evaluated in this study, e.g., between days 75 and 90 (February 2016) an increase of $1.5^{\circ} \mathrm{C}$ occurred concerning the rest of the evaluated period, and it was in this month that fruit growth increased rapidly explained by the influence of temperature. 
A framework related to day 75 is remarkable, where the highest amount of withering of young fruits or "Cherele Wills" was found in every evaluated treatment (Figure 3). Up to this point, the fruits showed an average of $12.7 \mathrm{~cm}$ in length and $4.6 \mathrm{~cm}$ in diameter. The products that reached that measurements were not aborted, instead of that, were physiologically recognized by the tree and were successful in achieving the crop and physiological maturity. Further, Rubiano (1988) reported that the wilt of young fruits is mainly due to the internal competition among fruits; nonetheless, it can also be influenced by an accentuated water deficit, coinciding with what was observed in trees without irrigation and with soft pruning (T3). In these, the highest number of aborted young fruits was observed, as can be seen in the growth curve for day 75 (month of February) that coincided with the first dry period of the year. The previous leads to the fact that if water deficiencies are not supplemented, this internal competition among fruits and the capacity of the tree to survive occurs, generating abortions and diminishing yield.

In relation to the incidence of main cocoa pests, a lower incidence percentage of $M$. roreri was observed in non-irrigated cocoa plants, and with strong pruning (T3), this was because strong pruning favors air circulation and does not generate an increase in relative humidity in the tree crown, which favors the development of the disease. In contrast, the trees without irrigation and soft pruning (T4) reached the highest incidence rate of the disease. The results coincided with what Phillips (1986), who observed that a relative humidity of $80.5 \%$ favors the germination of the conidia of $M$. roreri, but at lower humidity percentages there is no germination, and these conidia only germinate in the presence of a water film.

A lower incidence percentage of P.palmivora was observed in plants without irrigation and with strong pruning (T3), because this type of pruning improves air circulation in the tree canopy, reducing the relative humidity, a factor that favors the development of the disease. This result contrasted with what was observed in plants without irrigation and soft pruning (T4), which reached a higher incidence percentage of the disease.

Similar to the case of M. perniciosa, the incidence of P. palmivora was higher in the seasons in which there were high-intensity rains, and it was reduced in times in which the intensity of the rains decreased, independently of their frequency. Precipitation is one of the most important factors for the occurrence of an infection by P. palmivora, occurring this, days after heavy rains occur, as zoospores spread easily with the splash caused by rain on the ground and also by the water that runs off along the branches and trunks (Pérez et al., 2010). This coincides with a report that stated that the disease occurs in humid environments when there is not enough aeration, and when during irrigation, soil particles are splashed into the foliage (ICA, 2012).

Regarding the percentage of average incidence of M. dissimulatum, a higher percentage was observed in trees that received treatment $\mathrm{T} 2$, this because this type of pruning does not allow adequate light penetration and causes an excess of self-shading in the trees favoring the appearance and reproduction of this cocoa bug. On the other hand, trees that received treatments $\mathrm{T} 1$ and $\mathrm{T} 4$ had much lower incidence values of this pest due to the adequate penetration of the light to the fruits, which allowed natural control of the pest.

\section{Conclusions}

The highest yields and growth of cocoa fruits were obtained with the T2 (Drip irrigation + soft pruning), compared to treatments $\mathrm{T} 1, \mathrm{~T} 3$, and $\mathrm{T} 4$.

The lowest incidence of pests and diseases was found in cocoa trees which were treated with $100 \%$ ETo and strong pruning (T1), and $0 \%$ ETo and strong pruning (T3), indicating that $\mathrm{T} 1$ provided the necessary conditions for a good fruit development and improved air circulation in the tree canopy, reducing relative humidity, a factor that favors the development of the disease, no matter the irrigation sheet used.

With the results obtained in this study, it is recommended for future research in the cultivation of cloned cocoa, the use of factor $\mathrm{Kc}=1.5$ for the conditions found in Mercaderes, Cauca. 
Regarding the level or type of pruning from the technical and economic point of view, it is convenient to use soft pruning with an appropriate technical criterion and taking into account the phenological stage of the crop.

\section{Acknowledgments}

The authors on behalf of Corporación Colombiana de Investigación Agropecuaria (AGROSAVIA) wish to thank Fondo de Adaptación for financing the Project Risk Reduction and Adaptation to Climate Change, Adaptation Models and Agroclimatic Prevention (MAPA); also, to Association of Cocoa Producers of the Municipality of Mercaderes (ASPAEMERC) and to the cocoa producer Emilson López Meneses for all his good will, disposition and the support provided during the execution of the project.

\section{Cited literature}

Alcaráz, R. 1973. Relación de algunos factores climáticos con la producción de cocoa en la zona Atlántica de Costa Rica. CATIE Repositorio Institucional, CRI. http://repositorio.bibliotecaorton.catie.ac.cr/handle/11554/3788 (consultado 10 dic. 2018).

Allen, R.G., L.S. Pereira, D. Raes, y M. Smith. 2006. Evapotranspiración del cultivo: Guías para la determinación de los requerimientos de agua de los cultivos. FAO, Roma, ITA. http://www.fao.org/docrep/pdf/009/x0490s/x0490s.pdf (consultado 20 sept. 2018).

Andrade, H.J., M.A. Segura, D.S. Canal, M.J. Gómez, M.d.P. Martín, E. Sierra, I.G. Ortíz, J.J. Alvarado, y M. Feria. 2013. Estrategias de adaptación al cambio climático en sistemas de producción agrícola y forestal en el Departamento del Tolima. Universidad del Tolima, Ibagué, COL. http://www.ejecutortolima.gov.co/modulos/subprogramas/archivos_ evidencias/AdaptacionGobernacion\%20(1).pdf (consultado 5 nov. 2018).

Ayestas, E.D. 2009. Caracterización morfológica de cien árboles promisorios de Theobroma cacao L. en Waslla, RAAN, Nicaragua, 2009. Trabajo de graduación. World Cocoa Foundation, WA, USA. http://www.worldcocoafoundation.org/ wp-content/uploads/files_mf/ayestasvillega2009.pdf (consultado 20 sep. 2017).

Carr, M.K.V., and G. Lockwood. 2012. Cocoa. In: M.K.V. Carr, editor, Advances in irrigation agronomy: Plantation crops. Cambridge University Press, Cambridge, GBR. p. 53-75. doi:10.1017/CBO9780511998263.005

Chinin, R.M. 2015. Evaluación de tres formas de podas en cocoa CCN-51 y sistema de riego subfoliar con pistola senninger 3012. Tesis Ing. Agr., Universidad de Guayaquil, ECU.

CRC (Corporación Autónoma Regional del Cauca). 2010. Caraterización ambiental plan departamental de aguas y saneamiento básico: Departamento del Cauca. DOCPLAYER, ESP. https://docplayer.es/22011210-Pda-cauca-caracterizacionambiental-plan-departamental-de-aguas-y-saneamiento-basico-departamento-del-cauca-popayan-marzo-de-2010.html (consultado 15 dic. 2018).

Cubbage, F.W., R.R. Davis, y G.E. Frey. 2011. Guía para la evaluación económica y financiera de proyectos forestales comunitarios en México. Documento de trabajo forestal latinoamericano No 2. Banco Mundial, región de Latinoamérica y el Caribe, MEX. https://www.profor.info/sites/profor.info/files/Guia_para_la_evaluacion_economica_y_financiera_de_ proyectos_forestales_comunitarios_en_mexico.pdf (consultado 13 jun. 2017).

DANE (Dirección Administrativo Nacional de Estadística). 2016. Encuesta nacional agropecuaria ENA - 2016. DANE, Bogotá D.C., COL. https://www.dane.gov.co/files/investigaciones/agropecuario/enda/ena/2016/boletin_ena_2016.pdf (consultado 18 dic. 2017). 
Eskes, A.B., J.M.M. Engels, and R.A. Lass. (ed). 2000. Working procedures for cocoa germplasm evaluation and selection. Bioversity International, Turrialba, Cartago, CRI. http://www.bioversityinternational.org/fileadmin/user_upload/online_ library/publications/pdfs/Working_procedures_for_cocoa_germplasm_evaluation_and_selection_1998.pdf (accessed Dec. 15, 2018).

Gittinger, J.P. 1983. Análisis económico de proyectos agrícolas. 2da ed. Banco Mundial, WA, USA. http://documents.worldbank. org/curated/en/346331468182932744/pdf/UNN760PUB0SPAN00agricolas000Spanish.pdf (consultado 23 oct. 2017).

ICA (Instituto Colombiano Agropecuario). 2012. Manejo fitosanitario del cultivo de cocoa. (Theobroma cacao L.). Medidas para la temporada invernal. ICA, Bogotá D.C., COL. https:/www.ica.gov.co/getattachment/c01fa43b-cf48-497a-aa7f51e6da3f7e96/- (consultado 14 jul. 2017).

ICCO (International Cocoa Organization). 2017. ICCO Annual Report 2014/2015. ICCO, CIV. https://www.icco.org/about-us/ icco-annual-report.html (accessed Dec. 20, 2018).

Llinás, H. 2014. Introducción a la estadística matemática. Editorial Universidad del Norte, Barraquilla, COL.

López, S.A., Á. Sol-Sánchez, V. Córdova, y F. Gallardo. 2016. Efecto de la poda en plantaciones de cacao en el estado de Tabasco, México. Rev. Mex. Cienc. Agríc. 14:2807-2815.

Mete, M.R. 2014. Valor actual neto y la tasa de retorno: su utilidad como herramienta para el análisis y evaluación de proyectos de inversión. Fides Et Ratio 7:67-85.

Munguía, R., C. Vega, L. Orozco, y C. Astorga. 2009. Caracterización morfológica de cien árboles promisorios de Theobroma cacao L. en Waslala, RAAN, Nicaragua, 2009. World Cocoa Foundation, NW, USA. http://www.worldcocoafoundation. org/wp-content/uploads/files_mf/ayestasvillega2009.pdf (consultado 8 de nov. 2017).

Palencia, G.E., y L.A. Mejía. 2000. La poda en cacao: Manejo de la copa en clones. CORPOICA, COL. https://repository. agrosavia.co/bitstream/handle/20.500.12324/2130/41517_41478.pdf?sequence=1\&isAllowed=y (consultado 15 mar. 2017).

Pérez, M.I., L.F. Peñaranda, y M.M. Herazo. 2010. Impacto, manejo y control de enfermedades causadas por Phytophthora palmivora en diferentes cultivos. Universidad de Pamplona, COL.

Phillips, W. 1986. Evaluación de la resistencia de cultivares de cocoa (Theobroma cacao L.) a Moniliophthora roreri. Tesis M.Sc., Universidad de Costa Rica. Turrialba, CRI.

Puentes, G.A. 2011. Formulación y evaluación de proyectos agropecuarios. Ecoe Ediciones, Bogotá, Colombia.

Romero, J., y J. Proaño. 2008. Evaluación del efecto del riego por goteo y microaspersión en la productividad del cacao (Theobroma cacao)-CCN 51 en un suelo Ustifluvent tipic en la zona Chongon - Península de Santa Elena Provincia del Guayas. Sociedad Ecuatoriana de La Ciencia Del Suelo, ECU. http://www.secsuelo.org/wp-content/uploads/2015/06/12.Jorge-Romero.-Riego.pdf (consultado 20 jul. 2018).

Rubiano, A. 1988. Efecto de la fertirrigación y el riego por goteo en los rendimientos del cacao (Theobroma cacao L.). AGROSAVIA, COL. https://repository.agrosavia.co/handle/20.500.12324/15700?show=full

Sale, P.J.M. 1969. Extension growth of cacao under controlled temperature conditions. J. Hort. Sci. 44:189-193. doi:10.1080/0 0221589.1969.11514297

Salef, P.J.M. 1970. Growth, flowering and fruiting of cacao under controlled soil moisture conditions. J. Hortic. Sci. 45:99-118. doi:10.1080/00221589.1970.11514337

Sarabia, W.W. 2008. Diagnóstico sobre la rehabilitación y recuperación de la capacidad productiva de huertas tradicionales de cacao (Theobroma cacao L.). Tesis Ing. Agr., Universidad Agraria del Ecuador, ECU. 